\title{
Optimal dose and safety of molnupiravir in patients with early SARS-CoV-2: a phase 1, dose-escalating, randomised controlled study.
}

\section{Short Title: Optimal Dose and Safety of Molnupiravir}

Saye $\mathrm{H}$ Khoo $\dagger^{\star 1,2}$, Richard FitzGerald $\dagger^{2}$, Thomas Fletcher ${ }^{2,3}$, Sean Ewings ${ }^{4}$, Thomas Jaki ${ }^{5,6}$, Rebecca Lyon ${ }^{2}$, Nichola Downs ${ }^{4}$, Lauren Walker ${ }^{2}$, Olana Tansley-Hancock ${ }^{4}$, William Greenhalf ${ }^{1}$, Christie Woods ${ }^{2}$, Helen Reynolds ${ }^{1}$, Ellice Marwood ${ }^{4}$, Pavel Mozgunov ${ }^{5}$, Emily Adams ${ }^{3}$, Katie Bullock$^{1}$, Wayne Holman ${ }^{7}$, Marcin D Bula ${ }^{4}$, Jennifer L Gibney ${ }^{2}$, Geoffrey Saunders ${ }^{4}$, Andrea Corkhill $^{4}$, Colin Hale ${ }^{2}$, Kerensa Thorne ${ }^{4}$, Justin Chiong ${ }^{1}$, Susannah Condie ${ }^{4}$, Henry Pertinez ${ }^{1}$, Wendy Painter ${ }^{7}$, Emma Wrixon ${ }^{4}$, Lucy Johnson ${ }^{4}$, Sara Yeats ${ }^{4}$, Kim Mallard ${ }^{4}$, Mike Radford ${ }^{4}$, Keira Fines $^{4}$, Victoria Shaw ${ }^{1}$, Andrew Owen ${ }^{1}$, David G Lalloo ${ }^{3}$, Michael Jacobs ${ }^{8}$, Gareth Griffiths ${ }^{4}$.

$1 \quad$ University of Liverpool, UK

2 Liverpool University Hospital NHS Foundation Trust, UK

3 Liverpool School of Tropical Medicine, UK

4 Southampton Clinical Trials Unit, UK

5 University of Lancaster, UK

6 MRC Biostatistics Unit, University of Cambridge, UK

7 Ridgeback Biotherapeutics, Miami, USA

8 Royal Free London NHS Foundation Trust, UK

$\dagger \quad$ Contributed equally

Corresponding Author:

Professor S.H. Khoo

khoo@liverpool.ac.uk

University of Liverpool, 70 Pembroke Place,

Liverpool L69 3GF, UK

$\mathrm{T}+441517945560$

$F+441517945656$ 
medRxiv preprint doi: https://doi.org/10.1101/2021.05.03.21256309; this version posted May 5, 2021. The copyright holder for this preprint

(which was not certified by peer review) is the author/funder, who has granted medRxiv a license to display the preprint in perpetuity.

All rights reserved. No reuse allowed without permission.

\section{Conflicts of interest}

Potential conflicts of interest. WH is a cofounder, owner and advisor of/to Ridgeback Biotherapeutics LP. WP is employed by Ridgeback Biotherapeutics.

Potential conflicts of interest SK has received research funding from ViiV Healthcare, Gilead Sciences, and Merck for the Liverpool HIV Drug Interactions programme and for unrelated clinical studies. Unrelated to the current work, AO is a Director of Tandem Nano Ltd and co-inventor of patents relating to drug delivery. AO has received research funding from ViiV Healthcare, Merck, Janssen and consultancy from Gilead, ViiV and Merck not related to the current work. GG has received funding from Janssen-Cilag, Astra Zeneca, Novartis, Astex, Roche, Heartflow, Celldex, BMS, BionTech, Cancer Research UK, NIHR, British Lung Foundation, Unitaid, GSK for unrelated academic clinical trials and programme funding. WG has received funding from the Wellcome Trust.

No conflict. RF, TF, SE, TJ, RL, ND, LW, OTH, CW, HR, EM, PM, EA, KB, MB, JG, GS, AC, CH, KT, JC, SC, HP, EW, LJ, SY, KM, MR, KF, VS, DL, MJ

\section{Funding}

This work was supported by Ridgeback Biotherapeutics. The AGILE platform infrastructure is supported by the Medical Research Council [grant number MR/V028391/1] and the Wellcome Trust [grant number 221590/Z/20/Z]. 
medRxiv preprint doi: https://doi.org/10.1101/2021.05.03.21256309; this version posted May 5, 2021. The copyright holder for this preprint

(which was not certified by peer review) is the author/funder, who has granted medRxiv a license to display the preprint in perpetuity.

All rights reserved. No reuse allowed without permission.

\section{Abstract}

\section{Background}

AGILE is a phase Ib/lla platform for rapidly evaluating COVID-19 treatments. In this trial (NCT04746183) we evaluated the safety and optimal dose of molnupiravir in participants with early symptomatic infection.

\section{Methods}

We undertook a dose-escalating, open-label, randomised-controlled (standard-of-care) Bayesian adaptive phase I trial at the Royal Liverpool and Broadgreen Clinical Research Facility. Participants (adult outpatients with PCR-confirmed SARS-CoV-2 infection within 5 days of symptom onset) were randomised $2: 1$ in groups of 6 participants to $300 \mathrm{mg}, 600 \mathrm{mg}$ and $800 \mathrm{mg}$ doses of molnupiravir orally, twice daily for 5 days or control. A dose was judged unsafe if the probability of $30 \%$ or greater dose-limiting toxicity (the primary outcome) over controls was higher than $25 \%$. Secondary outcomes included safety, clinical progression, pharmacokinetics and virologic responses.

\section{Results}

Of 103 volunteers screened, 18 participants were enrolled between 17 July and 30 October 2020 . Molnupiravir was well tolerated at 400,600 or $800 \mathrm{mg}$ doses with no serious or severe adverse events. Overall, 4 of $4(100 \%), 4$ of $4(100 \%)$ and 1 of $4(25 \%)$ of the participants receiving 300 , 600 and $800 \mathrm{mg}$ molnupiravir respectively, and 5 of $6(83 \%)$ controls, had at least one adverse event, all of which were mild ( $\leq$ grade 2 ). The probability of $\geq 30 \%$ excess toxicity over controls at $800 \mathrm{mg}$ was estimated at $0.9 \%$.

\section{Conclusion}

Molnupiravir was safe and well tolerated; a dose of $800 \mathrm{mg}$ twice-daily for 5 days was recommended for Phase II evaluation. 
medRxiv preprint doi: https://doi.org/10.1101/2021.05.03.21256309; this version posted May 5, 2021. The copyright holder for this preprint (which was not certified by peer review) is the author/funder, who has granted medRxiv a license to display the preprint in perpetuity.

All rights reserved. No reuse allowed without permission.

\section{INTRODUCTION}

In addition to life-saving therapies for COVID-19, there is an urgent need for effective antivirals in mild to moderate disease in order to reduce disease burden, prevent hospitalisation and death and potentially decrease transmission of SARS-CoV-2. AGILE is a randomised multi-arm, multi-dose, phase $\mathrm{Ib} / \mathrm{lla}$ platform in the UK using a seamless Bayesian adaptive design ${ }^{1}$ to determine the safety, activity and optimal dose of multiple SARS-CoV-2 candidate therapeutics. Several candidates can be tested simultaneously (potentially sharing control group data) to increase efficiency.

We evaluated molnupiravir (EIDD-2801/MK-4482), for the treatment of COVID-19 in a seamless phase I/II trial. Molnupiravir is the prodrug of the ribonucleoside analogue 14 B-d-N4hydroxycytidine (NHC; EIDD-1931). Despite differences in model systems, activity of molnupiravir has consistently been demonstrated in-vitro and in animal models. In mice implanted with authentic human lung tissue, a prophylactic dose of $500 \mathrm{mg} / \mathrm{kg}$ given $12 \mathrm{~h}$ prior to inoculation with SARSCoV-2 and every $12 \mathrm{~h}$ thereafter dramatically reduced viral plaque forming units at 2 days post inoculation. ${ }^{2}$ Furthermore, a twice daily $200 \mathrm{mg} / \mathrm{kg}$ dose (but not $75 \mathrm{mg} / \mathrm{kg}$ ) was also able to reduce pulmonary viral RNA and improve lung histopathology in Syrian Golden Hamsters when initiated at the time of inoculation but with much lower efficacy if initiated $\geq 24 \mathrm{~h}$ after infection. ${ }^{3}$ Finally, molnupiravir significantly reduced viral titres in the nasal swabs and turbinate 4 days after infection in ferrets when given at $5 \mathrm{mg} / \mathrm{kg}$ twice daily initiated $12 \mathrm{~h}$ after inoculation or $15 \mathrm{mg} / \mathrm{kg}$ initiated $36 \mathrm{~h}$ after inoculation, ${ }^{4}$ and was able to block transmission between ferrets. Current data warrant investigation of molnupiravir in human patients including studies to define the appropriate dose for a human SARS-CoV-2 antiviral indication.

Molnupiravir has been evaluated in healthy volunteers in single (50-1600mg) and multiple (50$800 \mathrm{mg}$ for 5.5 days) ascending oral doses, and was found to be well-tolerated ${ }^{5}$. Preliminary data have also been presented from a study in patients with mild-to-moderate SARS CoV2 infection 
medRxiv preprint doi: https://doi.org/10.1101/2021.05.03.21256309; this version posted May 5, 2021. The copyright holder for this preprint (which was not certified by peer review) is the author/funder, who has granted medRxiv a license to display the preprint in perpetuity. All rights reserved. No reuse allowed without permission.

who received $200 \mathrm{mg}, 400 \mathrm{mg}$ or $800 \mathrm{mg}$ of molnupiravir twice daily for 5 days or placebo ${ }^{6}$. Virus was cultured from nasopharyngeal swabs in only $42.9 \%$ of all PCR-positive patients at baseline and of these, culture-negativity was seen in all 47 evaluable subjects receiving molnupiravir (regardless of dose) versus $24 \%$ subjects allocated to placebo.

Here we report phase $\mathrm{lb}$ results where we sought to determine the safety and tolerability of multiple ascending doses of molnupiravir in participants with symptomatic COVID-19 to recommend a dose for phase II. Secondary objectives included characterising adverse events (AEs), serious adverse events (SAEs), clinical outcomes (FLU-PRO, WHO Ordinal Scale, NEWS2 and mortality) as well as the pharmacokinetics of molnupiravir and its major metabolite EIDD-1931. 
medRxiv preprint doi: https://doi.org/10.1101/2021.05.03.21256309; this version posted May 5, 2021. The copyright holder for this preprint (which was not certified by peer review) is the author/funder, who has granted medRxiv a license to display the preprint in perpetuity.

All rights reserved. No reuse allowed without permission.

\section{METHODS}

\section{Study design and Participants}

This dose-escalation phase I study (NCT04746183) was designed as an open label, randomised, controlled Bayesian adaptive trial in adult early infection in the community, coordinated by the National Institute for Health Research (NIHR) Southampton Clinical Trials Unit with participants recruited into the NIHR Royal Liverpool and Broadgreen Clinical Research Facility (UK). Eligible participants were men and women aged $\geq 18$ years with PCR-confirmed SARS-CoV-2 infection who were within 5 days of symptom onset, free of uncontrolled chronic conditions, and ambulant in the community with mild or moderate disease. Women of childbearing potential and men were required to use two effective methods of contraception, one of which should be highly effective, throughout the study and for 50 days and 100 days thereafter respectively. Any of the following criteria excluded participants from the study: pregnant or breast feeding women, stage 4 (severe) chronic kidney disease, clinically significant liver dysfunction, SpO2 <95\% by oximetry or lung disease requiring supplementary oxygen, ALT and/or AST > 5 times upper limit of normal , platelets $<50 \times 10-9 / \mathrm{L}$, experiencing any $>=$ Grade 3 CTCAE v5 events, previously reported hepatitis C infection, known allergy to any study medication or having received any other experimental agents within 30 days of first dose of study drug. All participants provided written informed consent before enrolment. The study protocol was reviewed and approved by the UK Medicines and Healthcare product Regulatory Agency (MHRA) and West Midlands Edgbaston Research Ethics Committee.

\section{Randomisation and masking}

Four sequential molnupiravir dosing tiers were defined a priori $(300 \mathrm{mg}, 400 \mathrm{mg}, 600 \mathrm{mg}$ and $800 \mathrm{mg}$ BD for 5 days) with participants allocated using permuted blocks (block size 3, with no further stratification factors, generated by NIHR Southampton CTU statisticians) via MEDIDATA RAVE. Randomisation used a 2:1 allocation ratio so that within each cohort, 4 participants were randomly assigned to receive molnupiravir plus standard-of-care and 2 participants (controls) standard-ofcare alone. The study was open label so both participant and treating clinician were aware of the allocated treatment. 
medRxiv preprint doi: https://doi.org/10.1101/2021.05.03.21256309; this version posted May 5, 2021. The copyright holder for this preprint (which was not certified by peer review) is the author/funder, who has granted medRxiv a license to display the preprint in perpetuity.

All rights reserved. No reuse allowed without permission.

\section{Procedures}

Participants with laboratory-confirmed SARS-CoV-2 infection, or who had an illness compatible with COVID-19 (and who were subsequently confirmed to be positive) were screened against eligibility criteria, including presence and onset of symptoms within the previous 5 days. For safety reasons, in each cohort, the first participant randomised to molnupiravir (sentinel patient) was followed up until for 24 hours before any subsequent participants were randomised. All participants who received molnupiravir received drug after at least a two hour fasting period with a 4 hour period of observation after the first dose.

We utilised a Bayesian adaptive design to support decision making in this phase I study. Details are provided in Supplement S1. Briefly, a dose-toxicity model ${ }^{7}$ was established which describes the relationship between dose-limiting toxicity at day 7 and treatment dose (control, 300mg, $400 \mathrm{mg}, 600 \mathrm{mg}$ and $800 \mathrm{mg} \mathrm{BD}$ ) and updated following completion of each dosing tier - see figure 2. For each cohort, the Safety Review Committee (SRC) reviewed all available safety data including at least 7 days data for each participant in the cohort, and all accrued information on previous cohorts (up to a maximum follow-up of 28 days). This included AE data, vital signs data, ECG data and clinical laboratory evaluations, as well as any emerging data from other studies. Following SRC review, recommendations could be to de-escalate, escalate, remain at the same dose, or continue to phase II. A dose was deemed to be unsafe if there was a $\geq 25 \%$ chance that treatment was associated with a $>30 \%$ risk of dose-limiting toxicities at day 7 . The model recommended the next dose-level according to which level is the most likely to correspond to an increase of a $15-25 \%$ in the dose limiting toxicity rate over control. However, the SRC made the ultimate decision whether to accept that the current dose was safe and to dose escalate and could decide to skip a dose if it did not more than double and was deemed safe by the Bayesian model. Once the dose escalation Phase I was complete, the independent Data Monitoring and Ethics Committee reviewed data from the final SRC, along with their recommendations on the recommended phase II dose, to ratify the Recommend Phase 2 Dose. 
medRxiv preprint doi: https://doi.org/10.1101/2021.05.03.21256309; this version posted May 5, 2021. The copyright holder for this preprint (which was not certified by peer review) is the author/funder, who has granted medRxiv a license to display the preprint in perpetuity.

All rights reserved. No reuse allowed without permission.

\section{Outcomes}

The primary outcome was dose limiting toxicity (DLT) using CTCAE version 5 (grades 3 and above) measured over 7 days and CTCAE grading related to platelets and/or lymphocytes, assessed in all participants, who were randomly assigned and received at least one dose of molnupiravir (unless randomised to control). Secondary outcomes: for safety included AEs, SAEs, physical findings, vital signs and laboratory parameters; for pharmacokinetics included concentrations of molnupiravir and EIDD-1931 in plasma; for clinical included Patient Reported Outcome Measures (FLU-PRO), WHO COVID-19 Ordinal Scale (at days 15,29), NEWS2 (assessed during clinic days 15, 29), mortality (days 15, 29) and time from randomisation to death (up to day 29).

\section{Pharmacokinetic sampling}

Plasma was sampled at Day 1 and 5 to measure the concentrations of molnupiravir and its major active metabolite EIDD-1931. On each sampling day, $2 \mathrm{~mL}$ of venous blood was collected predose, at 30 mins, and at 1-, 2- and 4-hours post-dose. All samples were rapidly cooled on wet ice and centrifuged $(2000 \mathrm{~g}$ for $10 \mathrm{~min})$ within $30 \mathrm{~min}$ of sample collection. Within 10 minutes of completing centrifugation, $150 \mathrm{~mL}$ of plasma was mixed with $450 \mathrm{uL}$ of acetonitrile, vortexed and transferred to a $-80^{\circ} \mathrm{C}$ freezer prior to onward shipping for pharmacokinetic analyses. Drug concentrations were measured using a validated LC-MS/MS assay at Covance Clinical Laboratories, Leeds, UK.

Concentrations of EIDD-1931 in plasma on day 1 and day 5 were described using summary statistics (geometric mean $(90 \% \mathrm{Cl})$, mean, standard deviation, median and range) for each time point.

Key pharmacokinetic (PK) parameters such as area under the concentration-time curve 0-4 $\mathrm{h}$ $\left(\mathrm{AUC}_{0-4}\right)$, maximum concentration $(\mathrm{Cmax})$ and time to maximum concentration (Tmax) were determined by non-compartmental modelling methods (WinNonlin, Phoenix, v. 8.3, Pharsight, 
medRxiv preprint doi: https://doi.org/10.1101/2021.05.03.21256309; this version posted May 5, 2021. The copyright holder for this preprint (which was not certified by peer review) is the author/funder, who has granted medRxiv a license to display the preprint in perpetuity. All rights reserved. No reuse allowed without permission.

Mountain View, CA, USA) on day 1 and day 5 for each dose and summarised descriptively. Accumulation ratios to day 5 were calculated for EIDD-1931 $\mathrm{AUC}_{0-4}$ and $\mathrm{Cmax}$.

\section{Statistical analysis}

All analyses are reported according to CONSORT 2010 and ICH E9 guidelines on Statistical Principles in Clinical Trials. All enrolled participants were included in both the evaluable population and the safety population for analysis.

The primary endpoint of DLTs up to 7 days post first dose were modelled using a Bayesian dosetoxicity model based on Mozgunov et al. ${ }^{7}$ The relationship between dose and toxicity was modelled using a two-parameter logistic model, where information can be shared across doses; in particular, the DLT rate in controls informs estimates for the active doses. The prior distributions for this model were calibrated to maximise the proportion of correct selection under a range of dosetoxicity scenarios where each dose considered in the study was the optimum one. The toxicity risk in controls was a priori assumed to be $10 \%$. Further details are given in Supplement S1.

The dose-toxicity model was updated after every cohort of participants, and the final model is presented as estimated DLT rates for each dose, alongside equal-tail $95 \%$ credible intervals. For active doses, we also present estimated additional toxicity above controls, the probability that the DLT rate falls within $15-25 \%$ additional toxicity over controls (a pre-determined acceptable target range for toxicity) and the probability of at least $30 \%$ additional toxicity over controls (deemed as unacceptably toxic). This is supported by the same information for up to day 29.

Baseline demographics are summarised within each dose (and controls) using descriptive statistics. Clinical endpoints are similarly summarised at days 15 and 29 . The sample size was flexible, based on the need for the study to adapt to accruing safety data. Simulations to assess 
medRxiv preprint doi: https://doi.org/10.1101/2021.05.03.21256309; this version posted May 5, 2021. The copyright holder for this preprint (which was not certified by peer review) is the author/funder, who has granted medRxiv a license to display the preprint in perpetuity.

All rights reserved. No reuse allowed without permission.

model operating characteristics and to calibrate prior assumed four doses (plus controls), with cohorts of size six capped at a total of 30 participants.

Statistical analysis was undertaken in SAS version 9.4, STATA version 16 and R version 3.6 0.

\section{Role of funding source}

The funder of the study had no role in study design, study execution, data collection, data analysis, or data interpretation. WH and WP were non-voting members of the Safety Review Committee meetings as recommended by the MHRA, but did not participate in the Committee's decisionmaking. The statisticians SE, GS and KT had full access to all the data in the study and SK \& GG had final responsibility for the decision to submit for publication. 
medRxiv preprint doi: https://doi.org/10.1101/2021.05.03.21256309; this version posted May 5, 2021. The copyright holder for this preprint (which was not certified by peer review) is the author/funder, who has granted medRxiv a license to display the preprint in perpetuity.

All rights reserved. No reuse allowed without permission.

\section{RESULTS}

Of 103 potential participants (Figure 1) who attended for screening, 58 were excluded (31 had no signs or symptoms of COVID-19, 12 tested negative for SARS-CoV-2 by PCR, 7 had signs or symptoms that began after 5 days of planned first dose, 2 had an uncontrolled comorbidity, 3 did not meet contraceptive requirements, 1 did not meet the age range, 1 did not meet the mild/moderate disease criterion, 22 declined, 5 were screened between dosing cohorts and 1 was unknown). Eligible individuals were randomly assigned within three sequential dose cohorts (300mg, $600 \mathrm{mg} \mathrm{\&} 800 \mathrm{mg}$ ) of 6 participants each (i.e. a total of 18 participants within the phase 1 ) and dosed in the period between 17 July 2020, and 30 October 2020. The baseline characteristics of participants were similar across all groups (Table 1) with an overall median age of $56,72 \%$ (13/18) female and 33\% (6/18) having a WHO COVID ordinal score of 1 (ambulatory mild disease). The median number of days (range) from symptom onset to randomisation and treatment by the 18 participants was 4 (range 1-5).

All molnupiravir participants received at least 1 dose with 3/4 (75\%), 4/4 (100\%) and 3/4 (75\%) completing the full treatment in the 300,600 and $800 \mathrm{mg}$ cohort respectively. One participant on $300 \mathrm{mg} \mathrm{BD}$ only took 1 of 2 intended tablets for 2 of their treatment doses and one participant on $800 \mathrm{mg}$ BD took only two doses on day one, withdrawing from treatment for personal reasons. The median number of molnupiravir doses received (range) was 10 (8-10), 10 (10-10), 10 (2-10) and median number of days on molnupiravir treatment (and range) was $5.5(5-6), 5(5-5), 5(1-5)$ for the $300 \mathrm{mg}, 600 \mathrm{mg} \& 800 \mathrm{mg}$ cohorts respectively.

\section{Primary analysis}

No participants in any cohort experienced a DLT or a grade 3 or above change in lymphocytes or platelets (for those with a normal baseline value) or a 2 or more grade increment in lymphocytes or platelets (for those with grade 2 or 3 at baseline). Following review by the Safety Review Committee (SRC), dose cohort escalation went from $300 \mathrm{mg}$ to $600 \mathrm{mg}$ (skipping $400 \mathrm{mg}$ ) and then from $600 \mathrm{mg}$ to $800 \mathrm{mg}$. Bayesian model DLT point estimates, $95 \%$ credible interval, and the target 
medRxiv preprint doi: https://doi.org/10.1101/2021.05.03.21256309; this version posted May 5, 2021. The copyright holder for this preprint (which was not certified by peer review) is the author/funder, who has granted medRxiv a license to display the preprint in perpetuity.

All rights reserved. No reuse allowed without permission.

toxicity level of $20 \%$ over the controls are shown in Figure 2. For data up to day 7 , the maximum dose $(800 \mathrm{mg}$ ) had an estimated DLT rate of $11.0 \%$ (equal-tail $95 \%$ credible interval of 1.8 to $30 \cdot 4 \%$ ), with estimated $7 \cdot 4 \%$ additional toxicity over controls and a probability of additional toxicity $\geq 30 \%$ over controls of $0.9 \%$. As there were no DLTs recorded up to day 28 , the results for day 7 are the same for day 28 and so are not repeated. These data support $800 \mathrm{mg}$ BD as the recommended phase II dose.

\section{Analysis of secondary endpoints}

Adverse events were evenly distributed among the dose cohorts including controls. Overall, 4 of 4 $(100 \%), 4$ of $4(100 \%)$ and 1 of $4(25 \%)$ of the participants receiving 300,600 and $800 \mathrm{mg}$ of molnupiravir, and 5 of $6(83 \%)$ controls, had at least one adverse event, all of which were mild ( $\leq$ grade 2). Molnupiravir was generally well-tolerated compared with controls, and Table 2 describes the frequencies of events across the groups by system organ class and CTCAE term. No serious adverse events were reported. The most common symptoms were gastrointestinal (diarhoea, nausea), respiratory (cough), central nervous system (loss of smell or taste) and flu-like symptoms.

At day 15 all participants had a WHO ordinal scale of 1 or 2 , with a median score (range) of 1.5 (12), $1.5(1-2), 2$ (2-2) and $1.5(1-2)$ for molnupiravir 300mg, 600mg and $800 \mathrm{mg}$ and controls respectively. At day 15 the molnupiravir $300 \mathrm{mg}, 600 \mathrm{mg}$ and controls had a median NEWS2 Score of 0 (range $0-0$ ), with molnupiravir $800 \mathrm{mg}$ a median score of 1 (range $0-1$ ). Median $\mathrm{O} 2$ saturation (range) was 97 (97-100), 97 (96-99), 99.5 (97-100), 97 (96-99) for 300, 600 and 800mg molnupiravir and controls respectively with median FLU-PRO totals $0.4(0.2-10), 0.2(0.1-0.6), 0.1$ $(0-0.3)$ and $0.2(0-0.5)$ respectively (further details with comparable day 29 endpoints are provided in Supplement 2).

\section{Pharmacokinetics}

The prodrug molnupiravir was generally not detectable, or detected at low concentrations only at early timepoints $(0.5,1$ hour post-dose), at all 3 doses (Table 3$)$. Plasma concentrations of the 
medRxiv preprint doi: https://doi.org/10.1101/2021.05.03.21256309; this version posted May 5, 2021. The copyright holder for this preprint (which was not certified by peer review) is the author/funder, who has granted medRxiv a license to display the preprint in perpetuity. All rights reserved. No reuse allowed without permission.

nucleoside metabolite EIDD-1931 were detectable, and showed no accumulation between day 1 and day 5. At day 5, geometric mean NHC exposures (\%CV) over the first 4 hours of dosing $\left(\mathrm{AUC}_{0-4}\right)$ in the $300 \mathrm{mg}(\mathrm{N}=4), 600 \mathrm{mg}(\mathrm{N}=4)$ and $800 \mathrm{mg}(\mathrm{N}=3)$ dose were $3470(42 \cdot 4), 3880(56 \cdot 3)$ and $7880(39.0) \mathrm{ng} . \mathrm{h} / \mathrm{mL}$, with corresponding peak (Cmax) concentrations of $1620(51.0), 1820$ $(84.6)$ and $4180(28 \cdot 1) \mathrm{ng} / \mathrm{mL}$. Time to peak plasma concentration was $0.5-2.0$ hours. 
medRxiv preprint doi: https://doi.org/10.1101/2021.05.03.21256309; this version posted May 5, 2021. The copyright holder for this preprint (which was not certified by peer review) is the author/funder, who has granted medRxiv a license to display the preprint in perpetuity.

All rights reserved. No reuse allowed without permission.

\section{DISCUSSION}

To study the tolerability and safety of molnupiravir, we enrolled participants who presented within five days of symptoms, and who did not have severe disease, since we judged that the largest public health impact of this antiviral drug would be through deployment in the community for preventing hospitalisation. In untreated SARS-CoV-2 infection, viral load peaks in the first week of illness ${ }^{8}$ suggesting that early antiviral treatment may influence disease progression and potentially transmission.

We have established the safety and tolerability of molnupiravir in SARS-CoV-2 infected individuals, alongside a conventional phase I dose ranging study in healthy volunteers (NCT04392219). We have shown that a dose of $800 \mathrm{mg}$ bd of molnupiravir is safe and well-tolerated in participants with SARS CoV-2 infection; the plasma concentrations attained are within the target range based on scaling from animal models ${ }^{2,3}$. Adverse effects were commonly reported, affecting 9/12 and 5/6 participants on molnupiravir and controls respectively. All were mild (Grade 1-2) and included flulike and upper respiratory symptoms, headache, myalgia, diarrhoea and nausea which were also consistent with symptomatic COVID-19 disease.

AGILE utilises complex innovative trial design methodology to accelerate early phase evaluation of novel antiviral agents against SARS CoV-2. Our Bayesian approach was selected to optimise statistical efficiency and to accelerate decision-making. Drug safety is not definitively established during phase I and requires large numbers of individuals dosed in phase III or IV. Rather, the AGILE design allowed us to establish (within an accelerated timescale) that a dose of molnupiravir $800 \mathrm{mg}$ bd for 5 days was sufficiently safe to progress into our continuation phase lla placebocontrolled trial (where safety continues to be monitored). Since full reproductive toxicologic datasets were not available at the time of initiation, our study required stringent precautions to avoid pregnancy in participants or their partners.

To our knowledge this is the first published report describing the use of molnupiravir in SARS-CoV2 infected individuals. We observed comparable exposures of EIDD1931 to healthy volunteers, ${ }^{8}$ 
medRxiv preprint doi: https://doi.org/10.1101/2021.05.03.21256309; this version posted May 5, 2021. The copyright holder for this preprint (which was not certified by peer review) is the author/funder, who has granted medRxiv a license to display the preprint in perpetuity.

All rights reserved. No reuse allowed without permission.

and describe an approach for rapidly estimating a dose-toxicity relationship for phase II evaluation. Whether or not molnupiravir will prove effective in treating COVID-19 will be determined in phase II trials which are currently underway, including our own, but the paucity of potent antiviral agents in the COVID-19 pipeline strongly argues for such accelerated approaches to early phase drug development. 
medRxiv preprint doi: https://doi.org/10.1101/2021.05.03.21256309; this version posted May 5, 2021. The copyright holder for this preprint (which was not certified by peer review) is the author/funder, who has granted medRxiv a license to display the preprint in perpetuity.

All rights reserved. No reuse allowed without permission.

\section{Data sharing}

The AGILE Trial Steering Committee will consider all reasonable requests by health-care providers, investigators, and researchers to provide anonymised data to address specific scientific or clinical objectives. The AGILE investigators are committed to reviewing requests from researchers for access to clinical trial protocols, de-identified patient-level clinical trial data, and study-level clinical trial data.

\section{Acknowledgments}

We thank the AGILE Trial Steering Committee (Nicholas Paton (chair), Fred Hayden, Janet Darbyshire, Amy Lucas, Ulrika Lorch), the AGILE Safety Review Committee (Amitava Ganguli, Wendy Painter), our independent Data Monitoring and Ethics Committee (Andrew Freedman (chair), Richard Knight, Richard Peck, Stevan Julious), and the AGILE Scientific Advisory Board (Annalisa Jenkins (chair), Stevan Emmett, Sanjay Bhagani, Sheuli Porkess, Larry Zeitlin, Gary Kobinger).

We thank the following for trial support: Kelly Byrne, Karen Martin, Kelly Cozens, Sam Wilding, Michelle Light, Cleo Pike, Nadia Kontogianni, Rachel Byrne, Ana I Cubas-Atienzar, Thomas Edwards, Jayne Jones.

We acknowledge National Institute for Health Research infrastructure funding for the Liverpool Clinical Research Facility and the Southampton Clinical Trials Unit. We thank Dr John Powers, Leidos Biomedical and the National Institute for Allergy and Infectious Diseases (NIAID), National Institutes for Health for supplying the FLU-PRO Questionnaire. TJ was supported by the NIHR Cambridge Biomedical Research Centre (BRC-1215-20014) and by UK Medical Research Council (grant number: MC_UU_00002/14). The views expressed are those of the author(s) and not necessarily those of the NIHR or the Department of Health and Social Care. 
medRxiv preprint doi: https://doi.org/10.1101/2021.05.03.21256309; this version posted May 5, 2021. The copyright holder for this preprint (which was not certified by peer review) is the author/funder, who has granted medRxiv a license to display the preprint in perpetuity. All rights reserved. No reuse allowed without permission.

\section{Contributors Statement}

SK, GG, TJ, SE, RF, PM contributed to study design. SK, GG, TJ, SE, GS, KT, PM, HP contributed to data analysis and interpretation. RF led clinical conduct as the principal investigator of the clinical site. TF, LW, RL, MB participated in clinical assessment and data collection. KF participated in the management of pharmacovigilance. SC, EW, MR, LJ contributed to the digital data collection and data management of the trial. MR led set up of the randomisation system. WG, TF, VS, EA, KB, CH contributed to study bioanalysis. AC, ND, EM, OTH, SY, HR, JC, RL, CW, JB, AO, MJ, DGL contributed to study management and execution. KM contributed to monitoring activities. WP, WH contributed preclinical and safety data on molnupiravir. SK, GG, MJ, AO, DGL were involved in primary manuscript writing. All authors contributed to the final version of the manuscript. 
medRxiv preprint doi: https://doi.org/10.1101/2021.05.03.21256309; this version posted May 5, 2021. The copyright holder for this preprint (which was not certified by peer review) is the author/funder, who has granted medRxiv a license to display the preprint in perpetuity.

\section{References}

1 Griffiths, G. et al. AGILE-ACCORD: A Randomized, Multicentre, Seamless, Adaptive Phase

I/II Platform Study to Determine the Optimal Dose, Safety and Efficacy of Multiple Candidate Agents for the Treatment of COVID-19: A structured summary of a study protocol for a randomised platform trial. Trials. 21(1):1-3 (2020)

2 Wahl, A. et al. SARS-CoV-2 infection is effectively treated and prevented by EIDD-2801. Nature. 2021 Mar;591(7850):451-457.

3 Abdelnabi, R. et al. Molnupiravir (EIDD-2801) inhibits SARS-CoV2 replication in Syrian hamsters model. bioRxiv 2020.12.10.419242; doi: https://doi.org/10.1101/2020.12.10.419242

4 Cox RM, Wolf JD, Plemper RK. Therapeutically administered ribonucleoside analogue MK4482/EIDD-2801 blocks SARS-CoV-2 transmission in ferrets. Nature Microbiology. 6(1):11-8 (2021)

5 Painter, W.P. et al. Human Safety, Tolerability, and Pharmacokinetics of a Novel BroadSpectrum Oral Antiviral Compound, Molnupiravir, with Activity Against SARS-CoV-2. Antimicrob Agents Chemother. AAC.02428-20. doi: 10.1128/AAC.02428-20. Epub ahead of print (2021)

6 Painter WP, Sheahan T, Baric R, Holman W, Donovan J, Fang L, et al. Reduction in infectious SARS-CoV-2 in treatment study of COVID-19 with molnupiravir. (Personal communication). Presented at the 2021 Conference on Retroviruses and Opportunistic Infections (CROI 2021) Virtual on 6-10 March 2021. Abstract 777.

7 Mozgunov P, Jaki T, Paoletti X. Randomized dose-escalation designs for drug combination cancer trials with immunotherapy. Journal of Biopharmaceutical Statistics. 29(2):359-77 (2019)

8 Cevik M, Tate M, Lloyd O, Maraolo AE, Schafers J, Ho A. SARS-CoV-2, SARS-CoV, and MERS-CoV viral load dynamics, duration of viral shedding, and infectiousness: a systematic review and meta-analysis. The Lancet Microbe. 2(1):e13-e22 (2020) 
medRxiv preprint doi: https://doi.org/10.1101/2021.05.03.21256309; this version posted May 5, 2021. The copyright holder for this preprint (which was not certified by peer review) is the author/funder, who has granted medRxiv a license to display the preprint in perpetuity.

All rights reserved. No reuse allowed without permission.

\section{Figure Legends}

Figure 1: CONSORT diagram

Figure 2: Primary endpoint - dose toxicity plot up to day 7 (evaluable population)

\section{Supplementary Information Titles}

S1: Model-based dose-finding design

S2: Clinical endpoints day 15 and day 29 (Evaluable population) 
medRxiv preprint doi: https://doi.org/10.1101/2021.05.03.21256309; this version posted May 5, 2021. The copyright holder for this preprint (which was not certified by peer review) is the author/funder, who has granted medRxiv a license to display the preprint in perpetuity. All rights reserved. No reuse allowed without permission.

\section{TABLES}

TABLE 1: Baseline characteristics

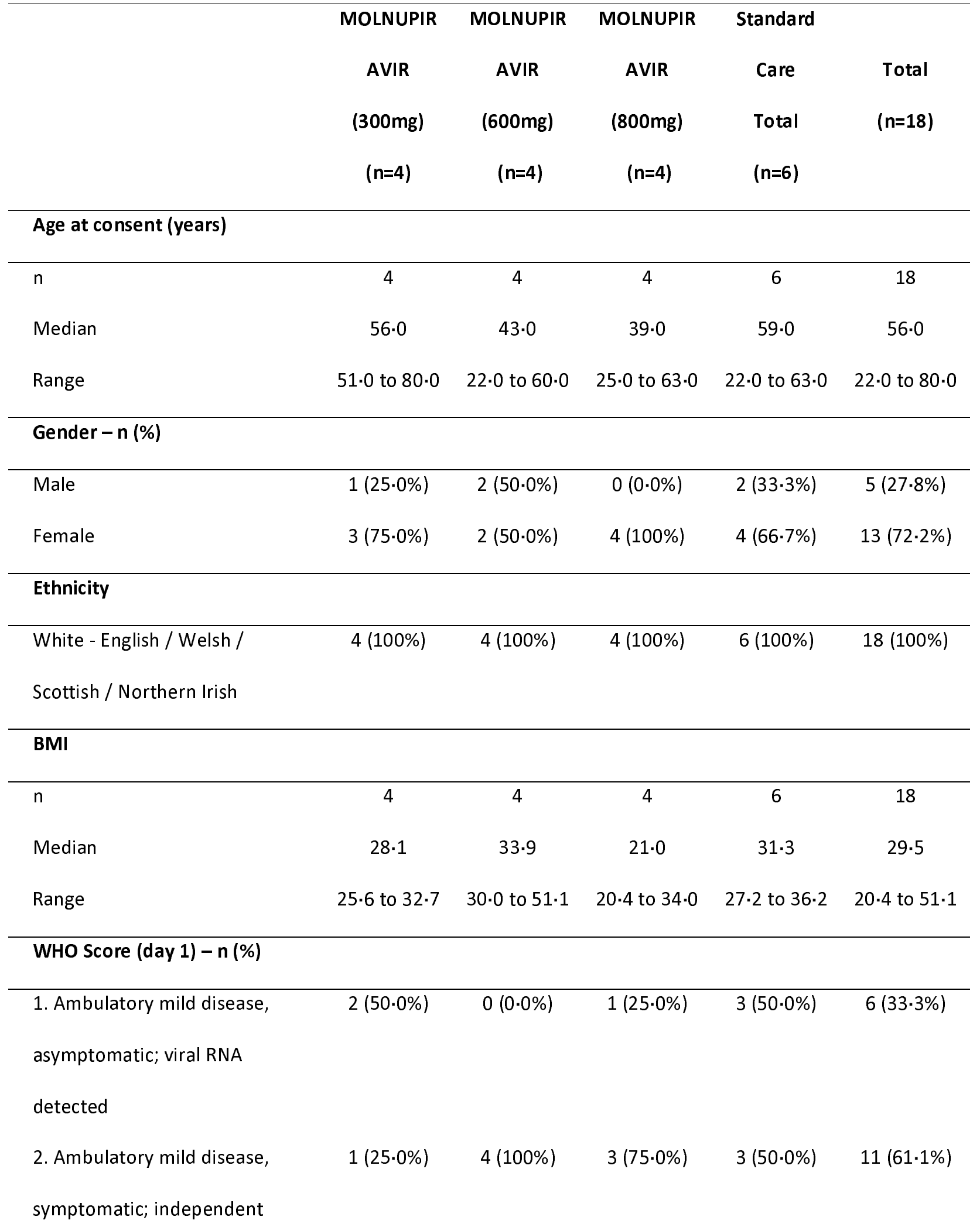


medRxiv preprint doi: https://doi.org/10.1101/2021.05.03.21256309; this version posted May 5, 2021. The copyright holder for this preprint (which was not certified by peer review) is the author/funder, who has granted medRxiv a license to display the preprint in perpetuity.

All rights reserved. No reuse allowed without permission.

\begin{tabular}{|c|c|c|c|c|c|}
\hline & MOLNUPIR & MOLNUPIR & MOLNUPIR & Standard & \\
\hline & AVIR & AVIR & AVIR & Care & Total \\
\hline & (300mg) & (600mg) & (800mg) & Total & $(n=18)$ \\
\hline & $(n=4)$ & $(n=4)$ & $(n=4)$ & $(n=6)$ & \\
\hline 3. Ambulatory mild disease, & $1(25 \cdot 0 \%)$ & $0(0 \cdot 0 \%)$ & $0(0 \cdot 0 \%)$ & $0(0 \cdot 0 \%)$ & $1(5 \cdot 6 \%)$ \\
\hline \multicolumn{6}{|c|}{ symptomatic; assistance needed } \\
\hline \multicolumn{6}{|l|}{ WHO Score (day 1) } \\
\hline$n$ & 4 & 4 & 4 & 6 & 18 \\
\hline Median & $1 \cdot 5$ & 2 & 2 & $1 \cdot 5$ & 2 \\
\hline Range & 1 to 3 & 2 to 2 & 1 to 2 & 1 to 2 & 1 to 3 \\
\hline \multicolumn{6}{|l|}{ NEWS2 Score (day 1) } \\
\hline$n$ & 4 & 4 & 4 & 6 & 18 \\
\hline Median & 0 & 0 & 0.5 & 0 & 0 \\
\hline Range & 0 to 1 & 0 to 0 & 0 to 1 & 0 to 0 & 0 to 1 \\
\hline \multicolumn{6}{|l|}{$\mathrm{O}_{2}$ Saturation \% (day 1 ) } \\
\hline $\mathrm{n}$ & 4 & 4 & 4 & 6 & 18 \\
\hline Median & $97 \cdot 5$ & $96 \cdot 5$ & $99 \cdot 0$ & $98 \cdot 0$ & $97 \cdot 5$ \\
\hline Range & 95.0 to 98.0 & 96.0 to 99.0 & $95 \cdot 0$ to $100 \cdot 0$ & $96 \cdot 0$ to $100 \cdot 0$ & 95.0 to 100 \\
\hline
\end{tabular}

\section{FLU-PRO total (day 1)}

\begin{tabular}{lccccc}
\hline $\mathrm{n}$ & 3 & 4 & 4 & 6 & 17 \\
Median & 0.7 & 0.8 & 1.0 & 0.6 & \\
Range & 0.4 to 1.3 & 0.8 to 1.4 & 0.5 to 1.6 & 0.3 to 1.6 & 0.3 to 1.6 \\
Missing from eCRF $-\mathrm{n}(\%)$ & $1(25.0 \%)$ & $0(0.0 \%)$ & $0(0.0 \%)$ & $0(0.0 \%)$ & $1(5 \cdot 6 \%)$
\end{tabular}

Time from symptom onset to

randomisation (days) ${ }^{2}$

$\mathrm{n}$

4

4

4

6

18 
medRxiv preprint doi: https://doi.org/10.1101/2021.05.03.21256309; this version posted May 5, 2021. The copyright holder for this preprint (which was not certified by peer review) is the author/funder, who has granted medRxiv a license to display the preprint in perpetuity.

All rights reserved. No reuse allowed without permission.

\begin{tabular}{|c|c|c|c|c|c|}
\hline & MOLNUPIR & MOLNUPIR & MOLNUPIR & Standard & \\
\hline & AVIR & AVIR & AVIR & Care & Total \\
\hline & (300mg) & (600mg) & (800mg) & Total & $(n=18)$ \\
\hline & $(n=4)$ & $(n=4)$ & $(n=4)$ & $(n=6)$ & \\
\hline Median & $4 \cdot 0$ & $4 \cdot 0$ & $3 \cdot 5$ & $4 \cdot 0$ & $4 \cdot 0$ \\
\hline Range & 3.0 to 4.0 & $4 \cdot 0$ to 4.0 & $2 \cdot 0$ to 4.0 & 1.0 to 5.0 & 1.0 to 5.0 \\
\hline
\end{tabular}

NOTE: Percentages are based on the number of patients in the study arm

${ }^{1}$ Reason for missing FLU-PRO:

${ }^{2}$ NOTE: Date of randomisation is the same as date of first dose for all patients randomised to molnupiravir 
medRxiv preprint doi: https://doi.org/10.1101/2021.05.03.21256309; this version posted May 5, 2021. The copyright holder for this preprint (which was not certified by peer review) is the author/funder, who has granted medRxiv a license to display the preprint in perpetuity.

TABLE 2: Overall toxicity Summary by CTCAE version 5 term - Safety population

MOLNUPIRAVIR MOLNUPIRAVIR MOLNUPIRAVIR

Standard

Characteristic

(300mg)

(600mg)

(800mg)

$(n=4)$

$(n=4)$

$(n=4)$

Care

Total

$(n=6)$

Number of patients that experienced at
4 (100\%)
$4(100 \%)$
$1(25 \%)$
$5(83 \cdot 3 \%)$

least one $\mathrm{AE}-\mathrm{n}(\%)$ *

Summary of AEs $-n(\%)$

\begin{tabular}{|c|c|c|c|c|}
\hline Cardiac disorders & $0(0.0 \%)$ & $0(0.0 \%)$ & $1(25 \cdot 0 \%)$ & $0(0.0 \%)$ \\
\hline Palpitations & $0(0.0 \%)$ & $0(0 \cdot 0 \%)$ & $1(25 \cdot 0 \%)$ & $0(0.0 \%)$ \\
\hline Ear and labyrinth disorders & $0(0.0 \%)$ & $0(0.0 \%)$ & $0(0.0 \%)$ & $1(16 \cdot 7 \%)$ \\
\hline Tinnitus & $0(0 \cdot 0 \%)$ & $0(0.0 \%)$ & $0(0 \cdot 0 \%)$ & $1(16 \cdot 7 \%)$ \\
\hline Eye disorders & $0(0.0 \%)$ & $1(25 \cdot 0 \%)$ & $0(0.0 \%)$ & $0(0.0 \%)$ \\
\hline Blurred Vision & $0(0 \cdot 0 \%)$ & $1(25 \cdot 0 \%)$ & $0(0 \cdot 0 \%)$ & $0(0.0 \%)$ \\
\hline Gastrointestinal disorders & $2(50 \cdot 0 \%)$ & $3(75 \cdot 0 \%)$ & $0(0.0 \%)$ & $2(33 \cdot 3 \%)$ \\
\hline Abdominal Pain & $1(25 \cdot 0 \%)$ & $0(0 \cdot 0 \%)$ & $0(0 \cdot 0 \%)$ & $0(0.0 \%)$ \\
\hline Diarrhea & $2(50 \cdot 0 \%)$ & $1(25 \cdot 0 \%)$ & $0(0 \cdot 0 \%)$ & $1(16 \cdot 7 \%)$ \\
\hline Dyspepsia & $0(0.0 \%)$ & $1(25 \cdot 0 \%)$ & $0(0 \cdot 0 \%)$ & $0(0.0 \%)$ \\
\hline Nausea & $1(25 \cdot 0 \%)$ & $2(50 \cdot 0 \%)$ & $0(0 \cdot 0 \%)$ & $1(16 \cdot 7 \%)$ \\
\hline Oral Dysesthesia & $1(25 \cdot 0 \%)$ & $0(0 \cdot 0 \%)$ & $0(0 \cdot 0 \%)$ & $0(0.0 \%)$ \\
\hline Vomiting & $1(25 \cdot 0 \%)$ & $0(0.0 \%)$ & $0(0 \cdot 0 \%)$ & $0(0.0 \%)$ \\
\hline $\begin{array}{l}\text { General disorders and administration } \\
\text { site conditions }\end{array}$ & $1(25 \cdot 0 \%)$ & $0(0.0 \%)$ & $0(0.0 \%)$ & $2(33 \cdot 3 \%)$ \\
\hline Fatigue & $1(25 \cdot 0 \%)$ & $0(0 \cdot 0 \%)$ & $0(0 \cdot 0 \%)$ & $0(0.0 \%)$ \\
\hline Flu Like Symptoms & $0(0.0 \%)$ & $0(0 \cdot 0 \%)$ & $0(0 \cdot 0 \%)$ & $2(33 \cdot 3 \%)$ \\
\hline Non-Cardiac Chest Pain & $0(0 \cdot 0 \%)$ & $0(0.0 \%)$ & $0(0.0 \%)$ & $1(16 \cdot 7 \%)$ \\
\hline
\end{tabular}




\begin{tabular}{|c|c|c|c|c|}
\hline Characteristic & $\begin{array}{l}\text { MOLNUPIRAVIR } \\
\begin{array}{c}\text { (300mg) } \\
(n=4)\end{array}\end{array}$ & $\begin{array}{l}\text { MOLNUPIRAVIR } \\
\begin{array}{c}(600 \mathrm{mg}) \\
(n=4)\end{array}\end{array}$ & $\begin{array}{l}\text { MOLNUPIRAVIR } \\
\begin{array}{c}(800 \mathrm{mg}) \\
(n=4)\end{array}\end{array}$ & $\begin{array}{l}\text { Standard } \\
\text { Care } \\
\text { Total } \\
\quad(n=6)\end{array}$ \\
\hline Infections and infestations & $1(25 \cdot 0 \%)$ & $2(50 \cdot 0 \%)$ & $0(0.0 \%)$ & $0(0.0 \%)$ \\
\hline Herpes Simplex Reactivation & $1(25 \cdot 0 \%)$ & $0(0 \cdot 0 \%)$ & $0(0.0 \%)$ & $0(0 \cdot 0 \%)$ \\
\hline $\begin{array}{l}\text { Infections And Infestations - Other, } \\
\text { Specify }^{1}\end{array}$ & $0(0.0 \%)$ & $1(25 \cdot 0 \%)$ & $0(0.0 \%)$ & $0(0 \cdot 0 \%)$ \\
\hline Thrush & $0(0.0 \%)$ & $1(25 \cdot 0 \%)$ & $0(0.0 \%)$ & $0(0 \cdot 0 \%)$ \\
\hline Investigations & $0(0.0 \%)$ & $1(25.0 \%)$ & $0(0.0 \%)$ & $0(0.0 \%)$ \\
\hline Alanine Aminotransferase Increased & $0(0 \cdot 0 \%)$ & $1(25 \cdot 0 \%)$ & $0(0.0 \%)$ & $0(0 \cdot 0 \%)$ \\
\hline GGT Increased & $0(0.0 \%)$ & $1(25 \cdot 0 \%)$ & $0(0 \cdot 0 \%)$ & $0(0 \cdot 0 \%)$ \\
\hline $\begin{array}{l}\text { Musculoskeletal and connective } \\
\text { tissue disorders }\end{array}$ & $1(25.0 \%)$ & $0(0.0 \%)$ & $0(0.0 \%)$ & $1(16 \cdot 7 \%)$ \\
\hline Chest Wall Pain & $1(25 \cdot 0 \%)$ & $0(0.0 \%)$ & $0(0.0 \%)$ & $0(0 \cdot 0 \%)$ \\
\hline Myalgia & $0(0 \cdot 0 \%)$ & $0(0 \cdot 0 \%)$ & $0(0 \cdot 0 \%)$ & $1(16 \cdot 7 \%)$ \\
\hline Nervous system disorders & $2(50 \cdot 0 \%)$ & $1(25 \cdot 0 \%)$ & $0(0.0 \%)$ & $2(33 \cdot 3 \%)$ \\
\hline Anosmia & $1(25 \cdot 0 \%)$ & $0(0.0 \%)$ & $0(0.0 \%)$ & $0(0 \cdot 0 \%)$ \\
\hline Dizziness & $1(25 \cdot 0 \%)$ & $0(0 \cdot 0 \%)$ & $0(0.0 \%)$ & $1(16 \cdot 7 \%)$ \\
\hline Dysgeusia & $1(25 \cdot 0 \%)$ & $0(0.0 \%)$ & $0(0.0 \%)$ & $1(16 \cdot 7 \%)$ \\
\hline Headache & $0(0.0 \%)$ & $1(25 \cdot 0 \%)$ & $0(0.0 \%)$ & $2(33 \cdot 3 \%)$ \\
\hline Psychiatric disorders & $0(0.0 \%)$ & $0(0.0 \%)$ & $1(25 \cdot 0 \%)$ & $0(0.0 \%)$ \\
\hline Anxiety & $0(0.0 \%)$ & $0(0.0 \%)$ & $1(25 \cdot 0 \%)$ & $0(0 \cdot 0 \%)$ \\
\hline Renal and urinary disorders & $1(25 \cdot 0 \%)$ & $0(0.0 \%)$ & $0(0.0 \%)$ & $1(16 \cdot 7 \%)$ \\
\hline Chronic Kidney Disease & $0(0.0 \%)$ & $0(0.0 \%)$ & $0(0.0 \%)$ & $1(16 \cdot 7 \%)$ \\
\hline Urine Discoloration & $1(25 \cdot 0 \%)$ & $0(0.0 \%)$ & $0(0.0 \%)$ & $0(0 \cdot 0 \%)$ \\
\hline
\end{tabular}




\begin{tabular}{|c|c|c|c|c|}
\hline Characteristic & $\begin{array}{l}\text { MOLNUPIRAVIR } \\
\begin{array}{c}(300 \mathrm{mg}) \\
(n=4)\end{array}\end{array}$ & $\begin{array}{l}\text { MOLNUPIRAVIR } \\
\begin{array}{c}\text { (600mg) } \\
(n=4)\end{array}\end{array}$ & $\begin{array}{l}\text { MOLNUPIRAVIR } \\
\begin{array}{c}(800 \mathrm{mg}) \\
(\mathrm{n}=4)\end{array}\end{array}$ & $\begin{array}{l}\text { Standard } \\
\text { Care } \\
\text { Total } \\
\quad(n=6)\end{array}$ \\
\hline $\begin{array}{l}\text { Respiratory, thoracic and mediastinal } \\
\text { disorders }\end{array}$ & $1(25 \cdot 0 \%)$ & $1(25 \cdot 0 \%)$ & $0(0.0 \%)$ & $1(16 \cdot 7 \%)$ \\
\hline Cough & $1(25 \cdot 0 \%)$ & $0(0 \cdot 0 \%)$ & $0(0.0 \%)$ & $1(16 \cdot 7 \%)$ \\
\hline Hoarseness & $0(0.0 \%)$ & $1(25 \cdot 0 \%)$ & $0(0.0 \%)$ & $0(0 \cdot 0 \%)$ \\
\hline Rhinorrhea & $1(25 \cdot 0 \%)$ & $0(0.0 \%)$ & $0(0.0 \%)$ & $0(0 \cdot 0 \%)$ \\
\hline Sore Throat & $0(0 \cdot 0 \%)$ & $1(25 \cdot 0 \%)$ & $0(0.0 \%)$ & $0(0.0 \%)$ \\
\hline Unclassified & $1(25 \cdot 0 \%)$ & $1(25 \cdot 0 \%)$ & $1(25 \cdot 0 \%)$ & $0(0.0 \%)$ \\
\hline Other - Bilateral Thigh Pain & $1(25 \cdot 0 \%)$ & $0(0 \cdot 0 \%)$ & $0(0 \cdot 0 \%)$ & $0(0 \cdot 0 \%)$ \\
\hline Other - Loose Stools & $0(0 \cdot 0 \%)$ & $0(0 \cdot 0 \%)$ & $1(25 \cdot 0 \%)$ & $0(0 \cdot 0 \%)$ \\
\hline Other - Worsening Fatigue & $0(0.0 \%)$ & $1(25 \cdot 0 \%)$ & $0(0.0 \%)$ & $0(0.0 \%)$ \\
\hline
\end{tabular}

Note: Percentages a re based on the number of patients in the study arm. CTCAE v $5 \cdot 0$ terms are used to classify AEs.

${ }^{1}$ This AE reported in Other specify free text field as "Chest infection".

* NB: All AEs were either Grade 1 or 2 
medRxiv preprint doi: https://doi.org/10.1101/2021.05.03.21256309; this version posted May 5, 2021. The copyright holder for this preprint (which was not certified by peer review) is the author/funder, who has granted medRxiv a license to display the preprint in perpetuity.

All rights reserved. No reuse allowed without permission.

TABLE 3: Geometric mean (\%CV) Pharmacokinetic parameters of EIDD-2801 following single and multiple dose administration of EIDD-2801

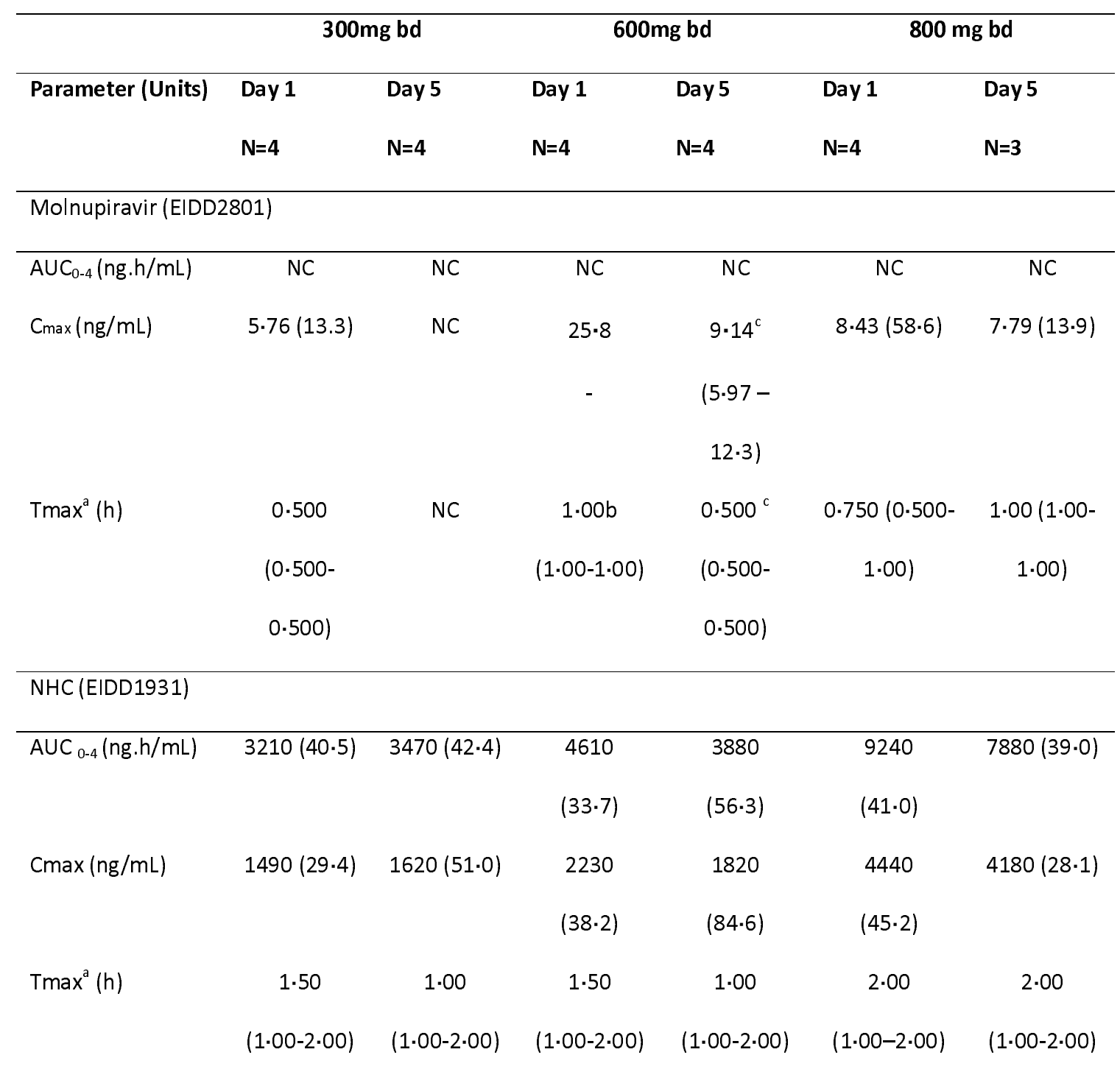

$\mathrm{NA}=$ Not applicable, $\mathrm{NC}=$ Not calculable,

$\mathrm{AUC}_{0-4}=$ Area under the time-concentration curve $(0-4 \mathrm{~h})$

Tmax $=$ Time to peak concentration

Cmax - Peak concentration

a Median (min-max) presented,

b $n=1$ with quantifiable concentrations out of 4 subjects

$c n=2$ with quantifiable concentrations out of 4 subjects 
medRxiv preprint doi: https://doi.org/10.1101/2021.05.03.21256309; this version posted May 5, 2021. The copyright holder for this preprint (which was not certified by peer review) is the author/funder, who has granted medRxiv a license to display the preprint in perpetuity.

\section{FIGURES}

\section{FIGURE 1}
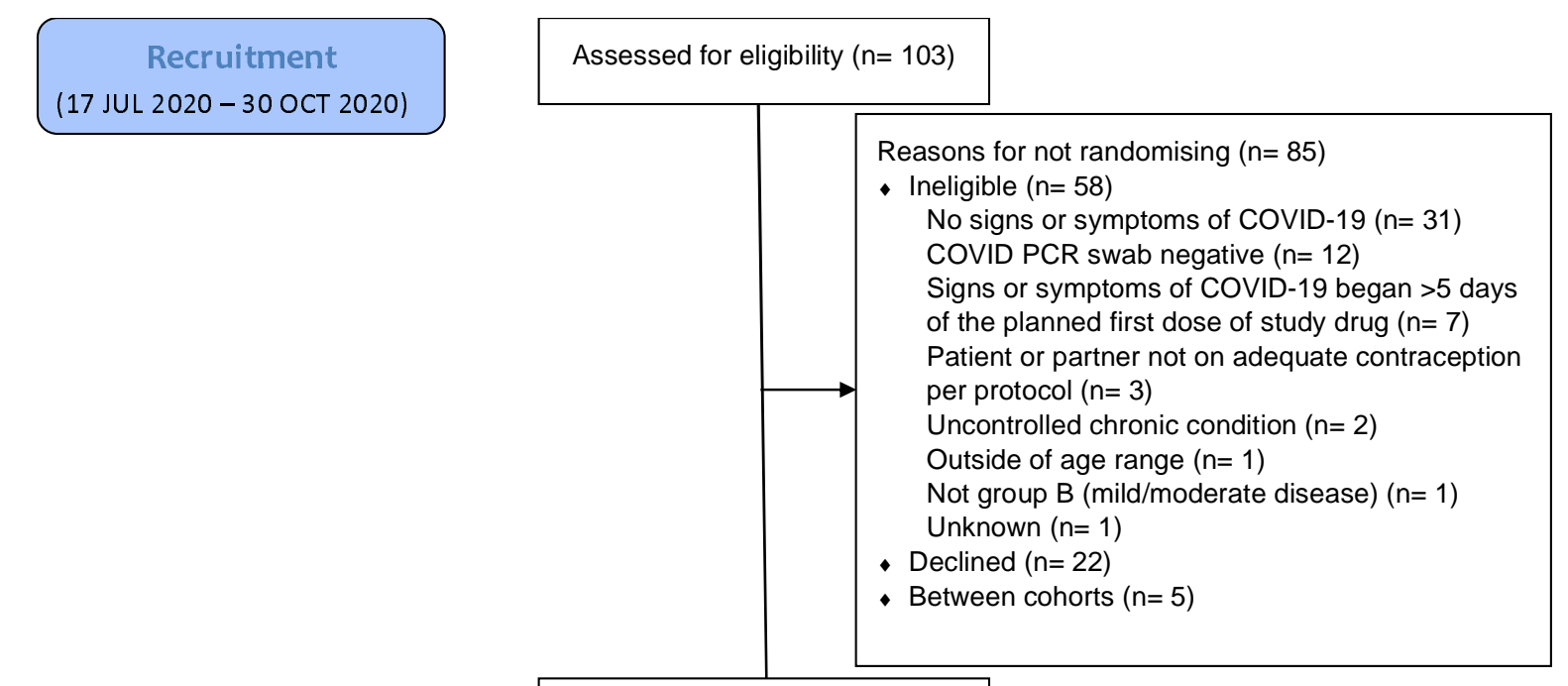

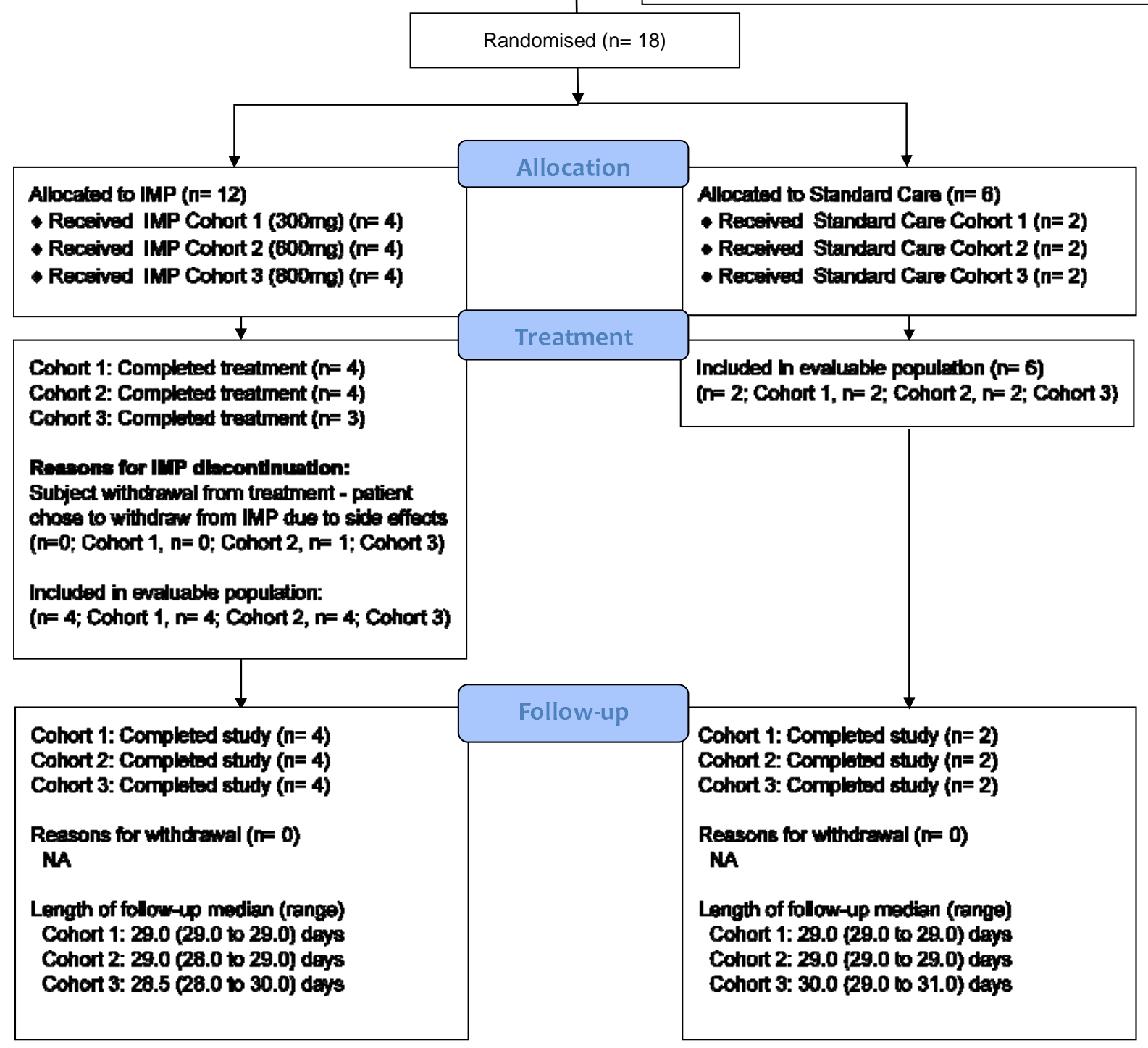


medRxiv preprint doi: https://doi.org/10.1101/2021.05.03.21256309; this version posted May 5, 2021. The copyright holder for this preprint (which was not certified by peer review) is the author/funder, who has granted medRxiv a license to display the preprint in perpetuity.

All rights reserved. No reuse allowed without permission.

\section{FIGURE 2}

a) Initial dose-toxicity model

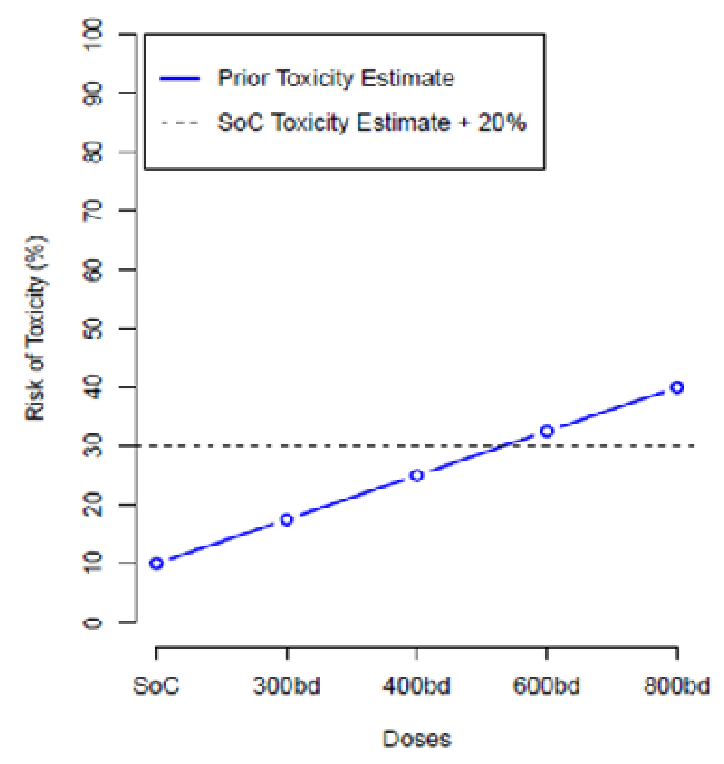

c) after completion of $600 \mathrm{mg}$ bd dose

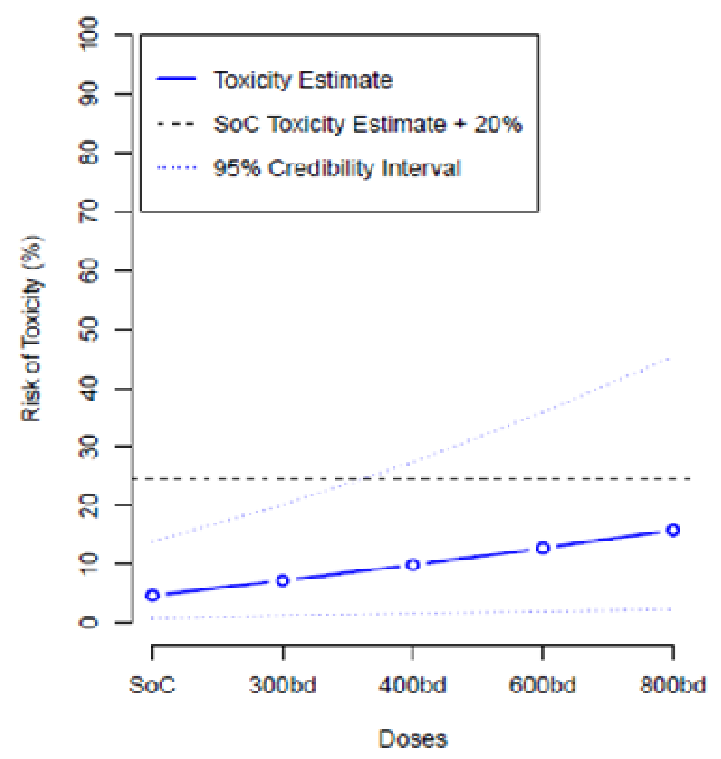

b) after completion of $300 \mathrm{mg}$ bd dase

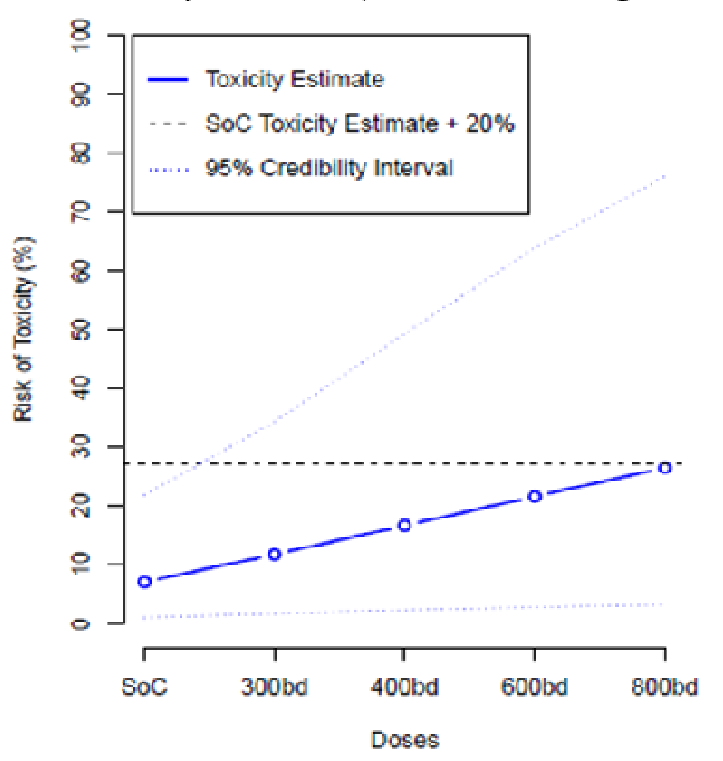

d) after completion of $800 \mathrm{mg}$ bd dose

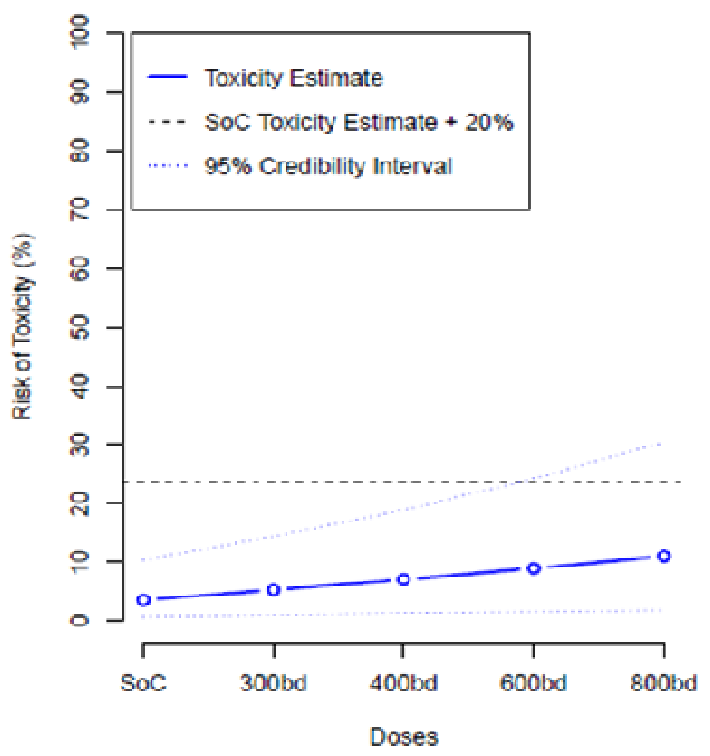

